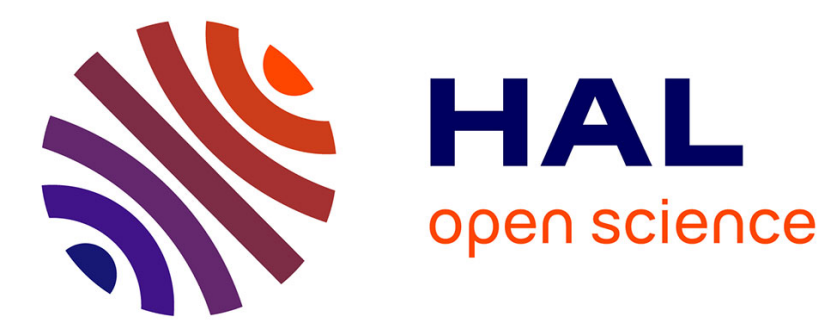

\title{
Microporous polyacrylate matrix containing hydrogen bonded nanotubular assemblies
}

\author{
Farid Ouhib, Emmanuelle Bugnet, Andrei Nossov, Jean-Luc Bonardet, \\ Laurent Bouteiller
}

\section{- To cite this version:}

Farid Ouhib, Emmanuelle Bugnet, Andrei Nossov, Jean-Luc Bonardet, Laurent Bouteiller. Microporous polyacrylate matrix containing hydrogen bonded nanotubular assemblies. Polymer, 2010, 51 (15), pp.3360-3364. 10.1016/j.polymer.2010.05.047 . hal-00604788

\section{HAL Id: hal-00604788 \\ https://hal.science/hal-00604788}

Submitted on 27 Aug 2020

HAL is a multi-disciplinary open access archive for the deposit and dissemination of scientific research documents, whether they are published or not. The documents may come from teaching and research institutions in France or abroad, or from public or private research centers.
L'archive ouverte pluridisciplinaire HAL, est destinée au dépôt et à la diffusion de documents scientifiques de niveau recherche, publiés ou non, émanant des établissements d'enseignement et de recherche français ou étrangers, des laboratoires publics ou privés. 


\title{
Microporous polyacrylate matrix containing hydrogen bonded nanotubular assemblies
}

\author{
Farid Ouhib ${ }^{\mathrm{a}, \mathrm{b}}$, Emmanuelle Bugnet ${ }^{\mathrm{a}}$, Andrei Nossov ${ }^{\mathrm{b}}$, Jean-Luc Bonardet ${ }^{\mathrm{b}}$, Laurent Bouteiller $^{\mathrm{a}}{ }^{\mathrm{*}}$ \\ ${ }^{a}$ UPMC Univ Paris 06, UMR 7610, Chimie des Polymères, F-75005 Paris, France, and CNRS, UMR \\ 7610, Chimie des Polymères, F-75005 Paris, France \\ ${ }^{b}$ UPMC Univ Paris 06, UMR 7197, Laboratoire de Réactivité des Surfaces (LRS), F-75005 Paris,
} France

\section{*Corresponding author. E-mail: laurent.bouteiller@upmc.fr}

\begin{abstract}
We report the straightforward photo-polymerization of polyacrylate films containing bisurea based self-assembled nanotubes. The obtained materials are characterized by gas adsorption measurements, 129Xe NMR spectroscopy and WAXS. The presence of the bis-ureas is shown by butane adsorption (at $273 \mathrm{~K}$ and ambient pressure) to be responsible for the formation of a significant microporosity. This porosity is however not detected by the classical argon adsorption procedure (at $77 \mathrm{~K}$ and low pressure). This effect is attributed to the contraction of the material at low temperature and pressure, and may be of general concern for other organic porous materials. One of the potential advantages of the present materials is that the porosity results from the self-assembled nanotubes and should therefore be independent of the matrix mechanical properties. It should in particular be possible to adjust the flexibility of the matrix by changing the monomer composition.
\end{abstract}

KEYWORDS. Self-assembly, ultramicroporous, nanotube.

\section{Introduction}

Most porous materials currently used in commercial applications are inorganic (zeolites, activated carbon, or clays, for example), however porous organic materials provide new opportunities in numerous technological areas, such as gas storage, separation processes or catalysis [1]. Their main potential advantages over inorganic materials are their lower specific weight, dielectric constant, and refractive index, and the virtually unlimited possibilities to functionalize their surface. In this context, several kinds of organic materials have been reported: on one hand, the assembly of well defined molecular building blocks can yield Covalent Organic Frameworks (COF) [2], Metal-Organic Frameworks (MOF) [3-5], or porous organic crystals [6-11], which enable both an exquisite control of the pore dimensions and a possible stimuli responsiveness. On the other hand, microporous materials can be obtained from rigidly crosslinked polymers [12-16]. In this case, a high surface area together with good mechanical properties can be obtained. In an attempt to combine a better control of the pore dimensions and good mechanical properties, it is also possible to polymerize a matrix in the presence of a self-assembled template. This approach has 
the additional advantage of an easier processability, because the pore formation and the chemical crosslinking steps are decoupled. The template can either remain in the final membrane (if the template presents an intrinsic porosity) [17-23], or it can be removed by dissolution or chemical degradation [24-26]. In the field of ultramicroporous materials (pore width $<1 \mathrm{~nm}$ ), only the former approach is feasible, and therefore, most systems reported consist of microchannels or nanotubes formed by assembly of macrocyclic compounds, where the macrocycle ensures the control of the pore width. In this case, the rigidity of the matrix is not essential, so that elastomeric ultramicroporous membranes can be envisaged.

In fact, self-assembled nanotubes can also be obtained from non-macrocyclic monomers [27-36], with the added advantage of a more direct synthetic accessibility than for macrocyclic compounds. In particular, bisurea based monomers (Scheme 1) are extremely simple compounds known to form micrometer long nanotubes in non polar solvents [35-40]. We therefore decided to investigate the possibility to use these bis-ureas as template to form ultramicroporous materials.
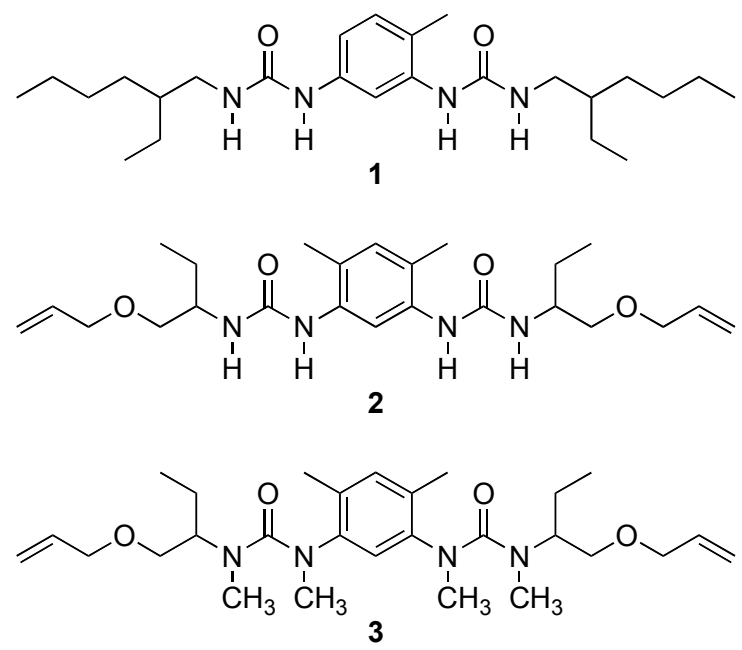

Scheme 1. Structure of hydrogen bonding bis-ureas 1 and $\mathbf{2}$, and reference bis-urea 3.

\section{Experimental}

\subsection{Synthesis of bis-ureas}

Bis-urea 1 was prepared from racemic 2-ethylhexylamine and 2,4-toluenediisocyanate as described previously [41]. The synthesis of bis-urea 2 from racemic 2-aminobutanol will be reported later. Synthesis of bis-urea 3: to a stirred solution of bis-urea $2(429.5 \mathrm{mg}, 0.963 \mathrm{mmol})$ in $5 \mathrm{~mL}$ of anhydrous dimethylformamide was added $\mathrm{NaH}(143.2 \mathrm{mg}, 5.778 \mathrm{mmol})$ at $0^{\circ} \mathrm{C}$. After 30 minutes, iodomethane $\left(820.1 \mathrm{mg}, 5.778 \mathrm{mmol}\right.$ ) was added to the solution under nitrogen, at $0^{\circ} \mathrm{C}$. The mixture was stirred at room temperature for $14 \mathrm{~h}$. The solution was diluted with $10 \mathrm{~mL}$ of dichloromethane, washed with water, dried over magnesium sulphate and evaporated to dryness. The product was purified by silica gel column chromatography ( $n$-hexane/ethylacetate, $3 / 1$ ) to give bis-urea 3 as a viscous oil (54\% yield). ${ }^{1} \mathrm{H}$ NMR 
(200MHz, DMSO): $\delta(\mathrm{ppm})=0.87\left(\mathrm{t}, 6 \mathrm{H}, \mathrm{CH}_{3}\right) ; 1.34\left(\mathrm{~m}, 4 \mathrm{H}, \mathrm{CH}_{2}\right) ; 2.05\left(\mathrm{~s}, 6 \mathrm{H}, \mathrm{Ar}_{-} \mathrm{CH}_{3}\right) ; 2.46(\mathrm{~s}, 6 \mathrm{H}$, $\left.\mathrm{N}-\mathrm{CH}_{3}\right) ; 3.05\left(\mathrm{~s}, 6 \mathrm{H}, \mathrm{N}-\mathrm{CH}_{3}\right) ; 3.29\left(\mathrm{~m}, 4 \mathrm{H}, \mathrm{CH}_{2}-\mathrm{O}\right) ; 3.65(\mathrm{~m}, 2 \mathrm{H}, \mathrm{CH}) ; 3.96\left(\mathrm{~d}, 4 \mathrm{H}, \mathrm{CH}_{2}-\mathrm{O}\right) ; 5.14$ (m, $\left.4 \mathrm{H}, \mathrm{CH}_{2}=\mathrm{CH}\right) ; 5.82\left(\mathrm{~m}, 2 \mathrm{H}, \mathrm{CH}=\mathrm{CH}_{2}\right) ; 6.83(\mathrm{~s}, 1 \mathrm{H}, \mathrm{Ar}-\mathrm{H}) ; 8.03(\mathrm{~s}, 1 \mathrm{H}, \mathrm{Ar}-\mathrm{H})$.

\subsection{Polymerization}

The bis-urea (1, 2 or 3) was dissolved under stirring in a mixture of isobornylacrylate (Aldrich) and divinylbenzene (Aldrich) $\left(95 / 5\right.$ by weight) at $60^{\circ} \mathrm{C}$. In the case of bis-ureas $\mathbf{1}$ and $\mathbf{2}$, a viscoelastic gel was obtained. The photoinitiator 2,2-dimethoxy-2-phenylacetophenone (DMPA, Ciba) (1\% by weight/ isobornylacrylate) was added to the mixture. The solution was placed between two glass slides separated by a $1 \mathrm{~mm}$ thick spacer, and then photo-polymerized under a DYNAX UV light curing system (2000 Flood Model, $400 \mathrm{~W}$ ) for 5 minutes. The obtained film was dried under vacuum for several days.

\subsection{Porosity measurements}

The polymer samples were first ground for 10 minutes, while cooled with liquid nitrogen, to yield a fine powder. The surface area and the porosity were measured by volumetry, with an ASAP 2020 Micromeritics apparatus using either argon at $77 \mathrm{~K}$ or butane at $273 \mathrm{~K}$ as adsorbent. The surface areas were calculated following the Brunauer, Emmet and Teller method (BET surfaces) and the microporous volumes were estimated from the point $\mathrm{B}$, point from which the adsorbed quantity of adsorbent begins to vary linearly with the relative pressure of the gas. It corresponds to the filling of micropores [42].

\section{$2.4 \mathrm{Xe} N M R$}

It has been proved that xenon NMR of adsorbed xenon is a very good tool to probe the micro and ultramicroporosity of porous materials [43]. Typically 300-500 mg of powdered polymer are placed in a cell. After treatment under vacuum at $60^{\circ} \mathrm{C}$, the cell is connected to a home-made volumetric apparatus. Xenon is introduced in the manifold and condensed in the cell at liquid nitrogen temperature. The cell is then sealed and brought back to the ambient temperature. The pressure of xenon in the manifold is determined so that the pressure in the cell after sealing is about 10 bars. Spectra are recorded with an AMX 300 Bruker spectrometer at the frequency of $83 \mathrm{MHz}$. The correct value of the pressure in the cell can be obtained from the chemical shift of the gas signal, which varies linearly with the xenon gas pressure.

\section{Results and Discussion}

\subsection{Design of the system}

Due to strong hydrogen bonding between urea groups, bis-urea 1 spontaneously forms long and rigid nanotubes in a wide temperature and concentration range. The inner diameter of the nanotubes is fixed by the supramolecular architecture and has been shown by host-guest studies and molecular simulations to be close to $7 \AA[36,38]$. Our aim is to dissolve the bis-urea in a suitable monomer where the nanotubes can self-assemble, and then to polymerize the monomer. Our assumption is that the monomers present inside 
the cavity of the nanotubes do not have enough conformational freedom to polymerize, so that it should be possible to evaporate them after polymerization of the matrix, and thus to obtain porous channels of $7 \AA$ diameter.

In low polarity solvents, bis-urea 1 nanotubes are isotropically dispersed and entangled, thus yielding gels. The viscoelastic nature of these gels proves that the nanotubes can break and recombine on the time-scale of seconds [44-46]. The dynamic character of the nanotubes has also been confirmed by isothermal titration calorimetry experiments, which show that dilution of the solution is responsible for a fast shortening of the nanotubes [37,47]. In some cases, the fast dynamics of this system is an advantage, because it ensures that a thermodynamic equilibrium is reached and that the self-assembled structures are stable over unlimited periods of time. In the present case however, the fast dynamics may allow the assemblies to reorganize during polymerization. To limit this potential issue, we need to use a fast polymerization process. Moreover, because a high polymerization temperature may destabilize the nanotubes, we selected a photo-polymerization process. Photo-initiated free radical polymerization has been widely used to polymerize a matrix containing non-dynamic self-assemblies [25,48-51]. We therefore sought to investigate if the same approach can be used in the case of a more dynamic system.

A second bis-urea (2) was also considered, to test the versatility of our approach. The xylene spacer in 2 (compared to the toluene spacer in 1) is expected to stabilize the nanotube structure due to a better preorganization of the monomer [39]. Moreover, the allylether side-chain was introduced to improve the solubility in moderately polar monomers. The solubility of both bis-ureas was then tested in a range of monomers (Table 1). Unexpectedly, bis-urea 1 does not form viscoelastic gels in any styrene-based monomers, although it was previously shown that $\mathbf{1}$ forms viscoelastic gels in a wide range of aromatic solvents (such as toluene, xylenes or ethylbenzene) [36]. In fact, 1 is insoluble in most styrene-based monomers; the only exceptions being 2-substituted styrene derivatives. Unfortunately, these monomers are too large to fit inside the nanotubes and therefore destabilize them [36]. Among the acrylic monomers tested, isobornylacrylate is the only monomer, which yields viscoelastic gels for both bis-ureas. This monomer was thus selected for further study. In particular, it was checked by FTIR that the characteristic signature of nanotubes is indeed obtained at room temperature (see Fig. S1 in Supporting Information) [35]. The thermal stability of the nanotubes was then checked by high sensitivity DSC: for $\mathbf{1}$ in isobornylacrylate, a transition temperature of $38^{\circ} \mathrm{C}$ was detected (see Fig. S2 in Supporting Information), whereas no transition was detected for 2 in isobornylacrylate (up to $80^{\circ} \mathrm{C}$ ), thus confirming the improved stability of the nanotubes in the case of bis-urea 2.

Finally, samples were prepared by photo-polymerization of mixtures containing a bis-urea, isobornylacrylate, divinylbenzene (as cross-linker) and DMPA (as photoinitiator). Here, two samples are described, the first (P1) is composed of 10\% 1 and 90\% monomer (isobornylacrylate + divinylbenzene) (95/5). The second sample (P2) is composed of 10\% 2 and $90 \%$ monomer (isobornylacrylate + divinylbenzene) $(95 / 5)$. It was checked by WAXS on the final samples that no phase separation occurred during polymerization (see Fig. S3 in Supporting Information). 
Table 1

Solubility at room temperature of bis-ureas $\mathbf{1}$ and $\mathbf{2}$ in vinylic monomers (1\% solutions); (F: fluid solution; G: viscoelastic gel; P: precipitates at room temperature after dissolution at $70^{\circ} \mathrm{C}$; I: insoluble; nt: not tested)

\begin{tabular}{|l|c|c|}
\hline monomer & bis-urea 1 & bis-urea 2 \\
\hline styrene & $\mathrm{I}$ & $\mathrm{I}$ \\
\hline divinylbenzene & $\mathrm{I}$ & $\mathrm{I}$ \\
\hline 2-methylstyrene & $\mathrm{F}$ & $\mathrm{nt}$ \\
\hline 3-methylstyrene & $\mathrm{P}$ & $\mathrm{nt}$ \\
\hline 4-methylstyrene & $\mathrm{F}$ & $\mathrm{nt}$ \\
\hline 2,5-dimethylstyrene & $\mathrm{P}$ & $\mathrm{nt}$ \\
\hline 2,4-dimethylstyrene & $\mathrm{F}$ & $\mathrm{nt}$ \\
\hline 2,4,6-trimethylstyrene & $\mathrm{P}$ & $\mathrm{nt}$ \\
\hline 4-isopropylstyrene & $\mathrm{P}$ & $\mathrm{nt}$ \\
\hline 4-tert-butylstyrene & $\mathrm{I}$ & $\mathrm{nt}$ \\
\hline 4-chlorostyrene & $\mathrm{P}$ & $\mathrm{nt}$ \\
\hline 4-fluorostyrene & $\mathrm{I}$ & $\mathrm{nt}$ \\
\hline 4-chloromethylstyrene & $\mathrm{G}$ & $\mathrm{nt}$ \\
\hline vinylcyclohexane & $\mathrm{I}$ & $\mathrm{G}$ \\
\hline methylmethacrylate & $\mathrm{I}$ & $\mathrm{G}$ \\
\hline butylacrylate & $\mathrm{G}$ & $\mathrm{G}$ \\
\hline isobornylacrylate & $\mathrm{I}$ & $\mathrm{I}$ \\
\hline butanedioldiacrylate & & \\
\hline
\end{tabular}




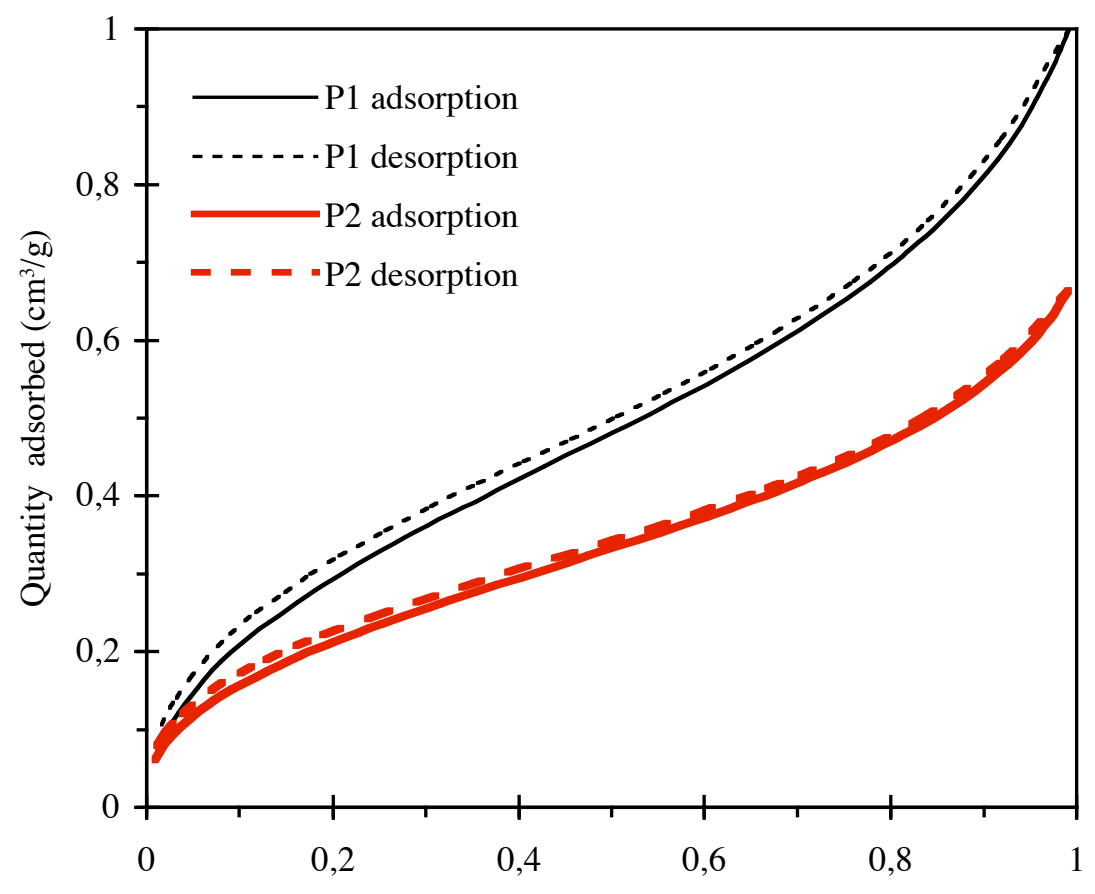

Relative pressure $\left(\mathrm{P} / \mathrm{P}^{\circ}\right)$

Fig. 1. Argon adsorption and desorption isotherms at 77K, for P1 and $\mathbf{P 2}$ samples.

\subsection{Characterization of porosity by gas sorption}

In order to evaluate the microporosity, argon adsorption and desorption of P1 and P2 were measured at $77 \mathrm{~K}$, and the results are shown in Fig. 1. In both cases, the obtained isotherm can be classified as type II and is consistent with a non-microporous material [42]. The apparent Brunauer-Emmett-Teller (BET) surface areas for $\mathbf{P 1}\left(1.1 \mathrm{~m}^{2} / \mathrm{g}\right)$ and $\mathbf{P 2}\left(0.73 \mathrm{~m}^{2} / \mathrm{g}\right)$ are very low. Moreover, the model of Horvath-Kawazoe [52] indicates a low microporous volume $\left(0.0005 \mathrm{~cm}^{3} / \mathrm{g}\right.$ for $\mathbf{P 1}$ and $0.0004 \mathrm{~cm}^{3} / \mathrm{g}$ for P2) and the complete absence of micropores with diameter lower than $1 \mathrm{~nm}$. This negative result obtained with conditions classically used to characterize inorganic materials may in fact be an artefact due to the experimental conditions of the adsorption and desorption measurement. Indeed, during the experiment the sample is placed under vacuum and at a very low temperature $(77 \mathrm{~K})$, which may cause a change in the supramolecular structure of the nanotubes. Knowing that the hydrogen bonds that maintain the tubular structure of bis-ureas are very sensitive to temperature and pressure, it is possible that if nanopores are present at room temperature and ambient pressure, they may reorganize and get obstructed at low temperature and low pressure. A similar contraction phenomenon has been observed in the case of nanoporous polyamides [15]. 


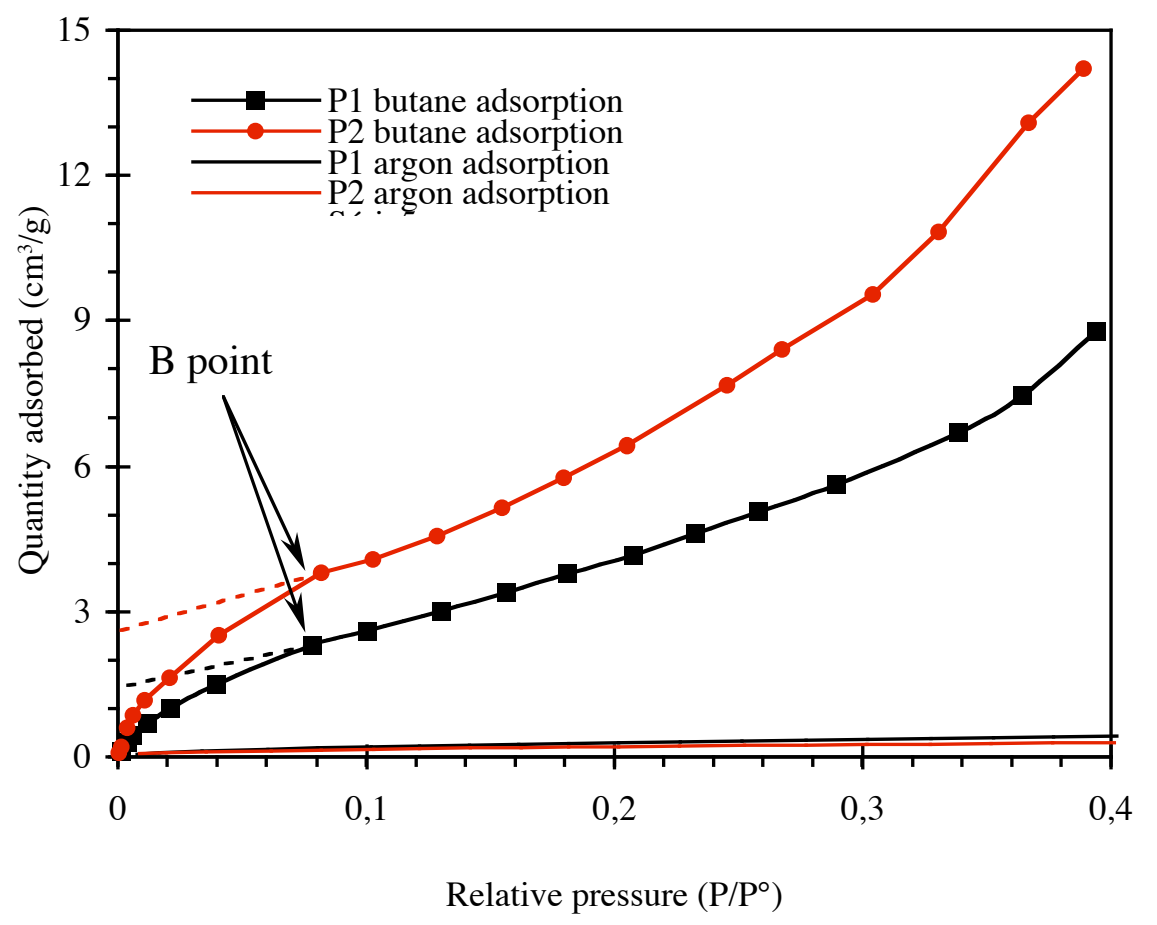

Fig. 2. Comparison between argon adsorption isotherm (obtained at 77K) and butane adsorption isotherm (obtained at 273K), for $\mathbf{P 1}$ and $\mathbf{P 2}$ samples.

To confirm this hypothesis, we conducted new measurements of adsorption and desorption, but with a gas that can be condensed at a temperature close to room temperature and ambient pressure. Butane is ideally suited for this, because it can be condensed at $273 \mathrm{~K}$ under atmospheric pressure, and it is characterized by a small enough encumbering surface area $\left(0.47 \mathrm{~nm}^{2}\right)$. The adsorption isotherms of butane at $273 \mathrm{~K}$ and argon at $77 \mathrm{~K}$ of $\mathbf{P 1}$ and $\mathbf{P 2}$ are compared in Fig. 2. Remarkably, the adsorbed quantity of butane by $\mathbf{P 1}$ and $\mathbf{P} 2$ is more than 20 times higher than that for argon (in the relative pressure range $0<\mathrm{P} / \mathrm{P}_{0}<0.4$ ). The BET surface areas for $\mathbf{P 1}$ and $\mathbf{P 2}$, calculated using butane as adsorbate at $273 \mathrm{~K}$, are respectively $65.4 \mathrm{~m}^{2} / \mathrm{g}$ and $111 \mathrm{~m}^{2} / \mathrm{g}$. These values of surface area are much higher than that obtained with argon as adsorbate at 77K. These results show clearly the high sensitivity of the microporous properties of $\mathbf{P 1}$ and $\mathbf{P 2}$ to the measuring conditions. Moreover, if we consider that the volume adsorbed at point B (Fig. 2) corresponds to the filling of the micropores, we find microporous volumes of 0.0095 and $0.015 \mathrm{~cm}^{3} \cdot \mathrm{g}^{-1}$, for $\mathbf{P 1}$ and $\mathbf{P 2}$ respectively. If we assume that all bis-ureas in the samples form nanotubes of $7 \AA$ inner diameter, we can estimate a maximum microporous volume of $0.01 \mathrm{~cm}^{3} \cdot \mathrm{g}^{-1}$ (see Supporting information). The experimental values are therefore of the correct order of magnitude. The higher microporous volume and surface area of sample $\mathbf{P 2}$ compared to sample $\mathbf{P 1}$ may be related to the better stability of nanotubes in the case of bis-urea 2. It is indeed possible that a larger fraction of bis-ureas are involved in the nanotubes in the case of bisurea 2. 
To confirm that the large quantity of butane adsorbed in the samples is due to the presence of porosity, and not to swelling of the polymer matrix by butane, the following blank experiments were performed. The first reference sample (R3) contains the methylated bis-urea 3 (Scheme 1), which cannot self-assemble into nanotubes, and the second reference sample (R4) is the crosslinked polyisobornylacrylate matrix containing no bis-urea. The four samples (P1, P2, R3 and R4) were prepared strictly under the same conditions. The reference samples were also analyzed by BET with butane as adsorbent at $273 \mathrm{~K}$. The obtained isotherms of adsorption are compared in Fig. 3, and show that $\mathbf{R 3}$ and $\mathbf{R} \mathbf{4}$ adsorb much less butane than P1 and P2. The calculated BET surface area for $\mathbf{R 3}$ and $\mathbf{R 4}$ are $3.1 \mathrm{~m}^{2} / \mathrm{g}$ and $13 \mathrm{~m}^{2} / \mathrm{g}$, respectively. The origin for the difference in butane adsoption between $\mathbf{R 3}$ and $\mathbf{R 4}$ is presently unknown, but the results clearly show that swelling of the matrix by butane cannot account for the large adsorption measured for P1 and P2. This therefore confirms the porosity of P1 and P2 samples.

\subsection{Xenon NMR measurements}

It is well known that 129Xe NMR of adsorbed xenon is a useful technique to probe the microporosity of solids. Initially, this technique has been successfully used in the case of zeolites and then extended to others microporous materials (such as porous silica, pillared clays, activated carbons, coals, or polymers...) [43]. In this later case, it is generally necessary to work at fairly high xenon pressures ( $\sim 10$ bars $)$ and with pulse delays of several seconds. We tried to use xenon NMR to confirm the existence of a microporosity in the samples. Fig. 4 presents xenon spectra adsorbed under about 10 bars on $\mathbf{P 2}$ and its $\mathbf{R 3}$ reference. In both cases, we observe two well defined signals: one near 4ppm which is due to the xenon gas (the value of the chemical shift allows us to determine the equilibrium pressure of xenon over the solid) and a second strongly shifted near 220ppm that we attribute to xenon in the polymer, in agreement with the literature [43]. Unfortunately the limited shift difference between the high field peaks in $\mathbf{P 2}$ and $\mathbf{R 3}$ does not allow to distinguish xenon adsorbed in the bis-urea nanotubes from xenon adsorbed in the polymer matrix. The reason is probably due to the similar chemical nature of the walls of the nanotubes and the polymer matrix and to the low microporous volume of the materials. However, the moderately larger peak width for $\mathbf{P 2}$ $(680 \mathrm{~Hz})$, compared to $\mathbf{R 3}(550 \mathrm{~Hz})$ may be an indication of a more heterogeneous environment in the case of $\mathbf{P 2}$, i.e. with xenon adsorbed either in the bis-urea pores or in the polymer matrix. 


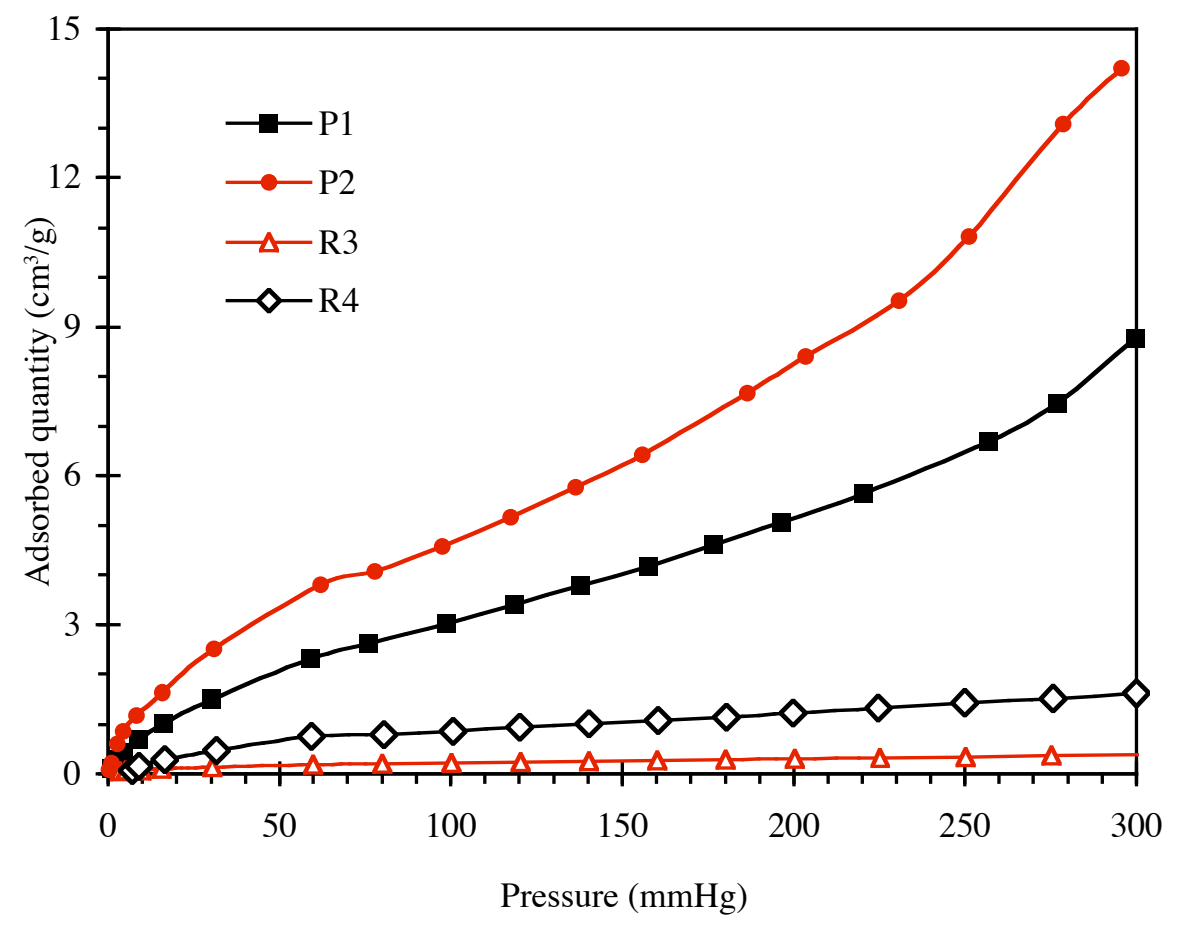

Fig. 3. Butane adsorption isotherms at 273K, for P1, P2, R3 and R4 samples.

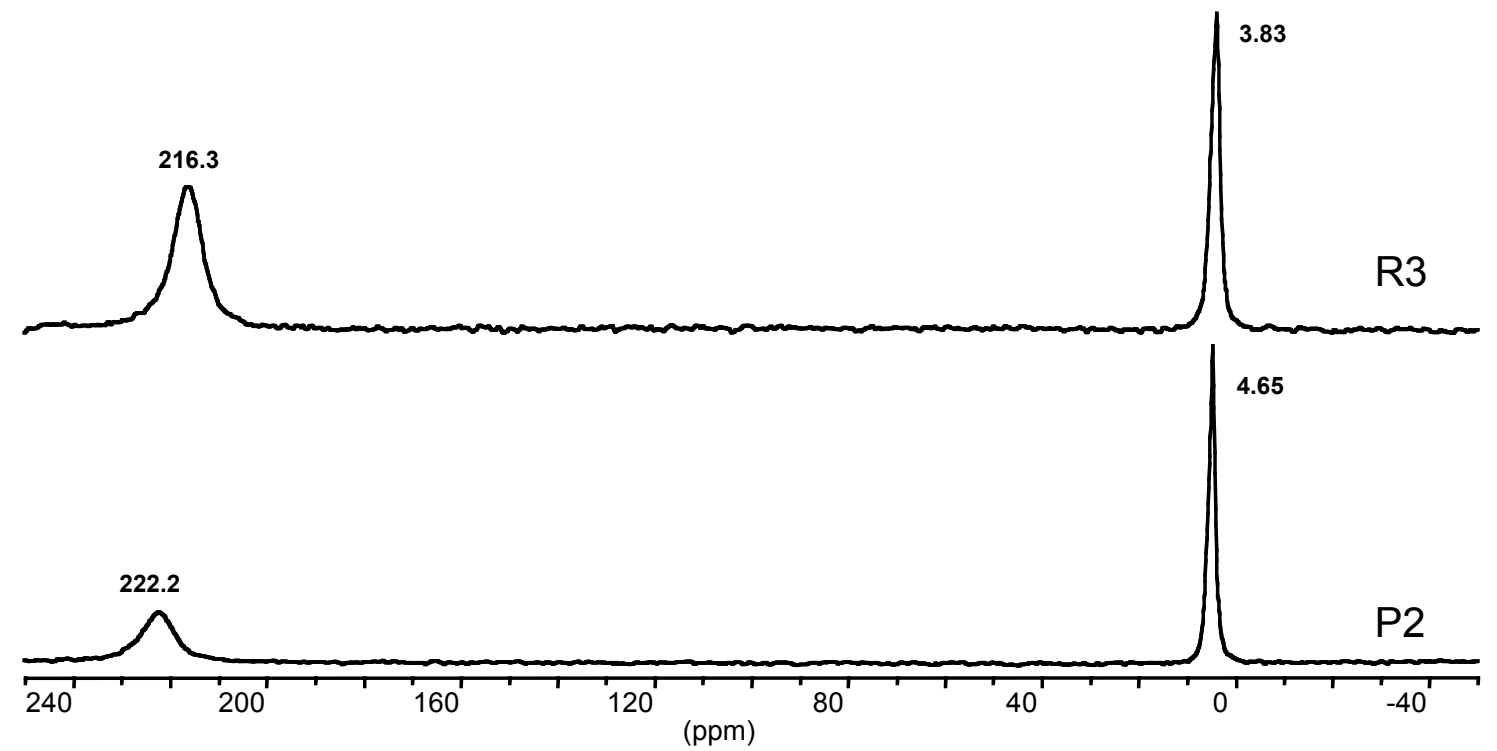

Fig. 4. Xenon NMR spectra of adsorbed xenon under 10 bars, for $\mathbf{P 2}$ and $\mathbf{R 3}$ samples.

\section{Conclusion}

We report the straightforward photo-polymerization of polyacrylate films containing bis-urea based selfassembled nanotubes. The presence of the bis-ureas is shown by butane adsorption (at $273 \mathrm{~K}$ and ambient pressure) to be responsible for the formation of significant microporosity. This porosity is however not detected by the classical argon adsorption procedure (at $77 \mathrm{~K}$ and low pressure). This effect, attributed to 
the contraction of the material at low temperature and pressure, may be of general concern for other organic porous materials. One of the potential advantages of the present materials is that the porosity results from the self-assembled nanotubes and should therefore be independent of the matrix mechanical properties. It should in particular be possible to adjust the flexibility of the matrix by changing the monomer composition.

Acknowledgements. Financial support from the French ANR program (ANR-06-BLAN-0159 zeoliplastic) is acknowledged.

Supporting Information Available. FTIR, DSC and WAXS data.

\section{References and Notes}

[1] Morris RE, Wheatley PS Angew Chem Int Ed 2008; 47; 4966-81.

[2] Côté AP, Benin AI, Ockwig NW, O'Keeffe M, Matzger AJ, Yaghi OM Science 2005; 310; 116670.

[3] Rosi NL, Eckert J, Eddaoudi M, Vodak DT, Kim J, O'Keeffe M, Yaghi OM Science 2003; 300; 1127-9.

[4] Chae HK, Siberio-Pérez DY, Kim J, Go Y, Eddaoudi M, Matzger AJ, O'Keeffe M, Yaghi OM Nature 2004; 427; 523-7.

[5] Dybtsev DN, Chun H, Kim K Angew Chem Int Ed 2004; 43; 5033-6.

[6] Khazanovich N, Granja JR, McRee DE, Milligan RA, Ghadiri MR J Am Chem Soc 1994; 116; 6011-2.

[7] Dewa T, Endo K, Aoyama Y J Am Chem Soc 1998; 120; 8933-40.

[8] Le Fur E, Demers E, Maris T, Wuest JD Chem Commun 2003; 2966-7.

[9] Sozzani P, Bracco S, Comotti A, Ferretti L, Simonutti R Angew Chem Int Ed 2005; 44; 1816-20.

[10] Thallapally KP, Wirsig TB, Barbour LJ, Atwood JL Chem Commun 2005; 4420-2.

[11] Yang J, Dewal MB, Shimizu LS J Am Chem Soc 2006; 128; 8122-3.

[12] Lee JY, Wood CD, Bradshaw D, Rosseinsky MJ, Cooper AI Chem Commun 2006; 2670-2.

[13] McKeown NB, Gahnem B, Msayib KJ, Budd PM, Tattershall CE, Mahmood K, Tan S, Book D, Langmi HW, Walton A Angew Chem Int Ed 2006; 45; 1804-7.

[14] Wood CD, Tan B, Trewin A, Su F, Rosseinsky MJ, Bradshaw D, Sun Y, Zhou L, Cooper AI Adv Mater 2008; 20; 1916-21.

[15] Weber J, Antonietti M, Arne T Macromolecules 2008; 41; 2880-5.

[16] Weder C Angew Chem Int Ed 2008; 47; 448-50.

[17] Gankema H, Hempenius MA, Moeller M, Johansson G, Percec V Macromol. Symp. 1996; 102; 381-90.

[18] Beginn U, Zipp G, Möller M Adv Mater 2000; 12; 510-3. 
[19] Beginn U, Zipp G, Mourran A, Walther P, Möller M Adv Mater 2000; 12; 513-6.

[20] Barboiu M, Cerneaux S, van der Lee A, Vaughan G J Am Chem Soc 2004; 126; 3545-50.

[21] Arnal-Hérault C, Pasc A, Michau M, Cot D, Petit E, Barboiu M Angew Chem Int Ed 2007; 46; 8409-13.

[22] Gevers LEM, Vankelecom IFJ, Jacobs PA Chem Commun 2005; 2500-2.

[23] Gin DL, Lu X, Nemade PR, Pecinovsky CS, Xu Y, Zhou M Adv Funct Mater 2006; 16; 865-78.

[24] Lee HK, Lee H, Ko YH, Chang YJ, Oh NK, Zin WC, Kim K Angew Chem Int Ed 2001; 40; 266971.

[25] Simon FX, Khelfallah NS, Schmutz M, Diaz N, Mésini PJ J Am Chem Soc 2007; 129; 3788-9.

[26] Nguyen TTT, Simon FX, Khelfallah NS, Schmutz M, Mésini PJ J Mater Chem 2010; 20; 3831-3.

[27] Percec V, Dulcey AE, Balagurusamy VSK, Miura Y, Smidrkal J, Peterca M, Nummelin S, Edlund U, Hudson SD, Heiney PA, Duan H, Magonov SN, Vinogradov SA Nature 2004; 430; 764-8.

[28] Percec V, Dulcey AE, Peterca M, Ilies M, Ladislaw J, Rosen BM, Edlund U, Heiney PA, Angew Chem Int Ed 2005; 44; 6516-21.

[29] Kaucher MS, Peterca M, Dulcey AE, Kim AJ, Vinogradov SA, Hammer DA, Heiney PA, Percec V J Am Chem Soc 2007; 129; 11698-9.

[30] Moralez JG, Raez J, Yamazaki T, Motkuri RK, Kovalenko A, Fenniri H J Am Chem Soc 2005; $127 ; 8307-9$.

[31] Johnson RS, Yamazaki T, Kovalenko A, Fenniri H J Am Chem Soc 2007; 129; 5735-43.

[32] Stoncius S, Orentas E, Butkus E, Ohrström L, Wendt OF, Wärnmark K J Am Chem Soc 2006; $128 ; 8272-85$.

[33] Pantos GD, Pengo P, Sanders JKM Angew Chem Int Ed 2007; 46; 194-7.

[34] Pantos GD, Wietor JL, Sanders JKM Angew Chem Int Ed 2007; 46; 2238-40.

[35] Bouteiller L, Colombani O, Lortie F, Terech P J Am Chem Soc 2005; 127; 8893-8.

[36] Pinault T, Isare B, Bouteiller L Chem Phys Chem 2006; 7; 816-9.

[37] Bellot M, Bouteiller L Langmuir 2008; 24; 14176-82.

[38] Shikata T, Nishida T, Isare B, Linares M, Lazzaroni R, Bouteiller L J Phys Chem B 2008; 112; 8459-65.

[39] Isare B, Linares M, Lazzaroni R, Bouteiller L J Phys Chem B 2009; 113; 3360-4.

[40] Isare B, Linares M, Zargarian L, Fermandjian S, Miura M, Motohashi S, Vanthuyne N, Lazzaroni R, Bouteiller L Chem Eur J 2010; 16; 173-7.

[41] Lortie F, Boileau S, Bouteiller L, Chassenieux C, Demé B, Ducouret G, Jalabert M, Lauprêtre F, Terech P Langmuir 2002; 18; 7218-22.

[42] Rouquerol F, Rouquerol LJ, Sing K Adsorption by powders and porous solids; Academic press (1999).

[43] Bonardet JL, Fraissard J, Gédéon A, Springuel-Huet MA Catal Review 1999; 41; 115-225. 
[44] van der Gucht J, Besseling NAM, Knoben W, Bouteiller L, Cohen Stuart MA Phys Rev E 2003; $67 ; 051106$.

[45] Knoben W, Besseling NAM, Bouteiller L, Cohen Stuart MA Phys Chem Chem Phys 2005; 7; 2390-8.

[46] Ducouret G, Chassenieux C, Martins S, Lequeux F, Bouteiller L J Coll Interface Sci 2007; 310; 624-9.

[47] Isare B, Bouteiller L, Ducouret G, Lequeux F Supramol Chem 2009; 21; 416-21.

[48] Gu W, Lu L, Chapman GB, Weiss RG Chem Commun 1997; 543-4.

[49] Tan G, Singh M, He J, John VT, McPherson GL Langmuir 2005; 21; 9322-6.

[50] Moffat JR, Seeley GJ, Carter JT, Burgess A, Smith DK Chem Commun 2008; 4601-3.

[51] Burguete MI, Galindo F, Gavara R, Izquierdo MA, Lima JC, Luis SV, Parola AJ, Pina F Langmuir 2008; 24; 9795-803.

[52] Horvath G, Kawazoe K J Chem Eng Japan 1983; 16; 470-475. 
for Table of Contents use only

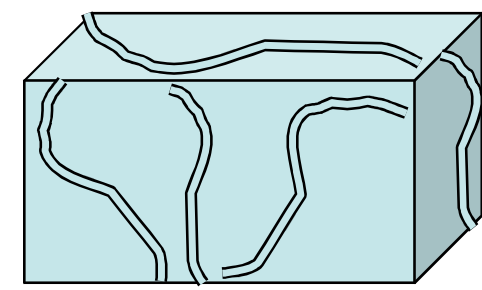

self-assembled nanotube $+$ monomer

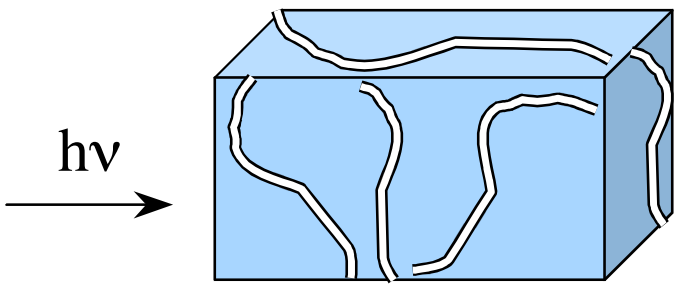

microporous matrix 